\title{
Using Digital Media to Increase Awareness for Ground Transportation and to Improve Airport Accessibility for Tourists in Portugal
}

\author{
Cindy Christensen ${ }^{1}$ \\ ${ }^{1}$ Department of Informatics Engineering, Faculty of Engineering, University of Porto, Porto, \\ Portugal (christensen.cindy@hotmail.com) ORCID 0000-0001-8379-9695
}

\begin{abstract}
In recent years, Portugal has seen an influx in foreign tourists across various major cities including Lisbon, Porto, Faro and more. With the spike of tourism, it is necessary to provide better options for public transportation for the local population as well for foreign tourists. Currently, in major cities such as Porto and Lisbon the public transportation is adequate; however, it can often be confusing for tourists to figure out various systems between buses, metro, local and regional trains. It is often the case that many of the arriving passengers do not speak Portuguese and are often unaware if there are adequate public transportation options. By providing passengers and arriving tourists' easily accessible digital platforms such as a mobile application that they can download on their phone relating to ground transportation, Portugal can mitigate the negative environmental impacts from the use of taxi and vehicular transportation instead of public transportation. Also, the digital platforms such as a web-based, mobile application, installed billboards, or signs can help travelers to easily access ground transportation options. Besides, travelers can also be informed about the costs, environmental impacts as well as other necessary information. By combining digital media and transportation, policy makers can manage and mitigate the effects of tourism on the local environment as well as to ensure that tourists can explore and travel in a sustainable manner.
\end{abstract}

Author Keywords. Transportation, Technology, Human Computer Interaction.

Type: Research Article

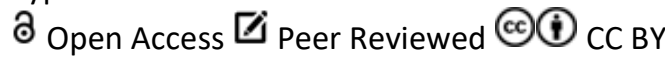

\section{Introduction}

International tourism has been steadily increasing around the world as people feel more comfortable traveling to various destinations across the globe. According to data from the World Travel \& Tourism Council (2018), travel and tourism is an important sector that is made up of $10.4 \%$ of the world's Gross Domestic Product (GDP), created 313 million jobs, and accounted for $9.9 \%$ of total global employment in 2017 . With an increase in tourism, more and more people are using transportation to visit museums and other monuments. While Uber and local taxis are convenient options for many tourists, others are interested in public transportation, yet, they are unsure of how to use them, especially in a new country.

Many major international airports across the globe are now finding ways to improve ground transportation options as well as to reduce reliance on private cars (Brasseur et al. 2016). This research will attempt to educate travelers and improve their decision-making analysis, by guiding them towards more sustainable transport options for airport ground access through the use of digital media, marketing strategy, and edutainment. 


\section{State of the Art}

In 2017, after winning several prestigious international awards, the number of foreign tourists traveling to Portugal increased by $12 \%$ in comparison to previous years, to approximately 12.7 million international travelers (Bugge 2018). Portugal has been dubbed by many travel magazines as the preferred destination due to its warm weather, low cost, safety, and other benefits for travelers. For the past decades, the government of Portugal has launched several successful marketing campaigns to promote the tourism industry and places to visit in Portugal. Recently, in 2018, Turismo de Portugal won a gold award for its campaign "Cannot Skip Portugal" in the category of Travel \& Tourism "Awards Media Marketing \& Advertising" (Turismo de Portugal 2019). The marketing strategy attracted many visitors who were curious about the country and as a result, the total revenue from accommodation from touristic activities brought in a record 3.7 billion euros in 2017 (Instituto Nacional de Estatística 2018). In addition to the "Cannot Skip Portugal" campaign, other prizes were also awarded to the National Tourism Authority in various categories including Digital \& Social Networks, International Markets, and more (Turismo de Portugal 2019).

In 2017, Portugal won a total of 37 awards from the 24th Annual World Travel Awards in the Europe category (Teixeira 2017). Portugal continues to be a popular destination in Europe, especially since the city of Porto was elected Best European Destination in 2012, 2014, and 2017 (Best Destinations in Europe 2017). In addition to Porto, other cities in Portugal such as Lisbon, Braga, and Faro are also well known for tourism. According to Banco de Portugal, tourists spending increased by $23 \%$ in comparison to the previous year and tourists will continue to contribute towards various sectors within the country as tourism increases year after year (Instituto Nacional de Estatística 2018). Statistics show that in 2006, Portugal welcomed 6.8 million international visitors, while in 2017 that number tripled to 21.2 million international visitors (World Tourism Organization 2018). In 2017, international tourists visiting Portugal were categorized as follows: $20.9 \%$ from the United Kingdom, $13.8 \%$ from Germany, 9.9\% from France, 9.9\% from Spain, and the remaining were made up from tourists from North America, as well as Asian regions such as Macau and Hong Kong (Instituto Nacional de Estatística 2018).

\subsection{Continuous outlook for tourism}

According to the latest data from the United Nations, 2017 marks one of the highest growth in international tourist arrivals since 2010, with Europe leading the way in comparison to the rest of the world. Figure 1 below shows that approximately 672 million arrived in Europe which marks an increase of more than $8 \%$ in comparison to the previous years data (World Tourism Organization 2018). Data from the United Nations supports the theory that international tourism around the world is at an increasing trend per UNWTO's long-term forecast of 3.8\% per year from 2010 to 2020 (World Tourism Organization 2018). As people travel more for personal and professional reasons, airports around the world play a more vital role in the transportation of people and goods. In 2017, 57\% of those that traveled, arrived at their destination by air, and statistics show that $55 \%$ traveled for leisure, $27 \%$ for visiting friends, $13 \%$ for business, and $6 \%$ for other reasons (World Tourism Organization 2018). According to the International Civil Aviation Organization (2018), 4.1 billion passengers traveled by air in 2017 which is an increase of $7.1 \%$ since the previous year. 


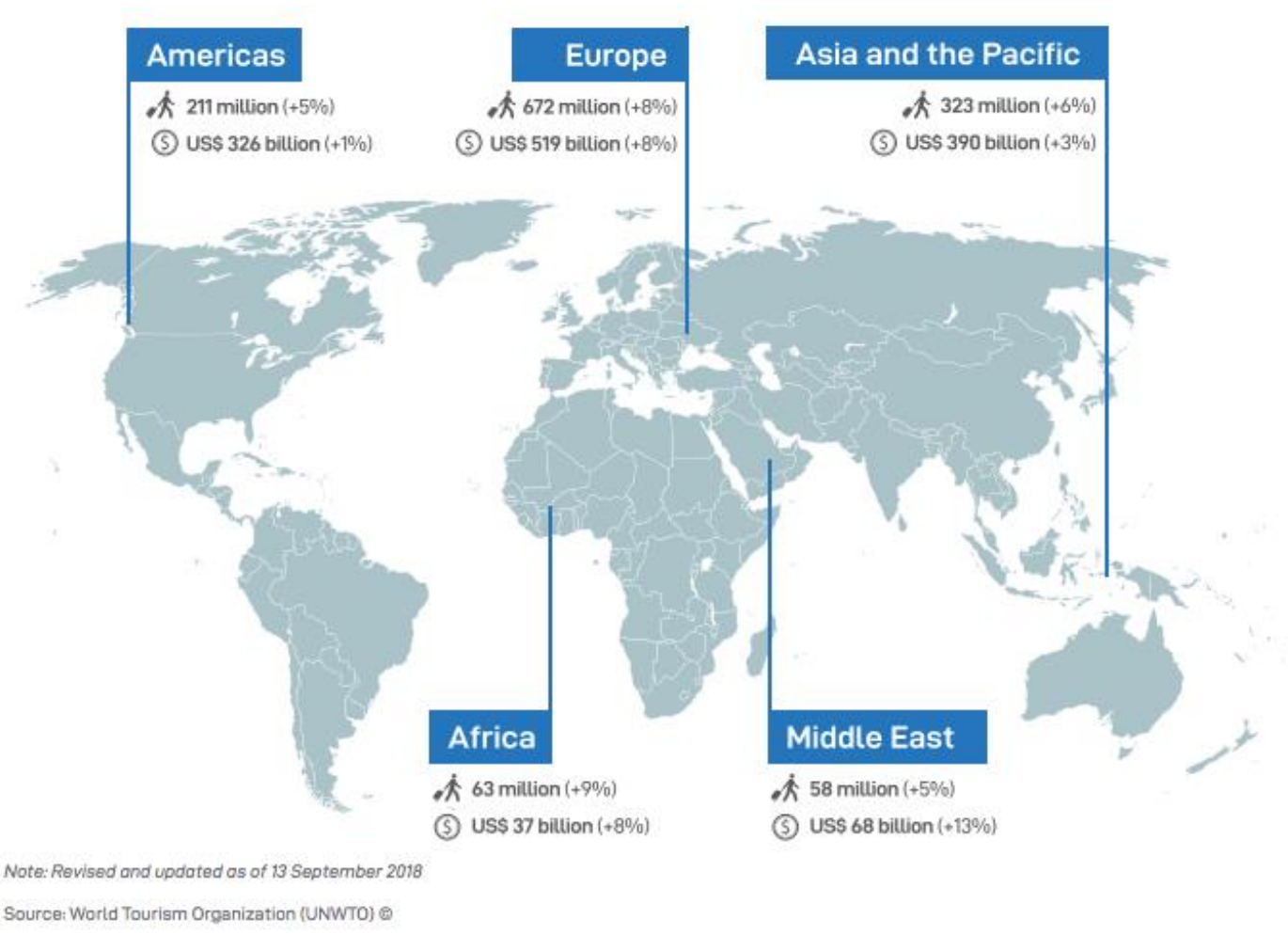

Figure 1: Data on International arrivals around the world

(World Tourism Organization 2018)

\subsection{Encouraging the use of public transportation surround airports}

Since many travelers often require to transport their suitcases from and to the airports, private cars and taxis are often the preferred mode of airport ground transportation. To mitigate environmental costs, public transport to the airport has been provided in many biggest international airport hubs in the world; however, attracting customers to use public transport has been a continuous challenge (Pasha and Hickman 2016).

The following data from the National Academies of Sciences, Engineering, and Medicine (2008), provides an insight into some of the most successful usages of public transportation for air travel around the world:

- Oslo, Norway: 64\%

- Hong Kong International Airport: 63\%

- Narita International Airport, Japan: 59\%

- Shanghai Pudong International Airport, China: 51\%

- Zurich Airport, Switzerland: $47 \%$

- Vienna International Airport, Austria: $41 \%$

- London Stansted Airport, UK: 40\%

- San Francisco International Airport, San Francisco, USA: 23\%

- John F. Kennedy International Airport, New York City, USA: 19\%

- General Edward Lawrence Logan International Airport, Boston, USA: 18\%

Having a reliable transit system connecting downtown to the airport is one of the most crucial steps in the development of a major city. In Portugal, two cities stand out as having impressive infrastructure when it comes to connecting to the airports, and those cities are Lisbon and Porto. Despite having a reliable public transportation metro system in these cities, many of the arriving passengers do not speak Portuguese and are often unaware of various public 
transportation options. As a result, travelers often opt for taxis, Uber or private car options. Traveling can often be tiring; therefore, having a digital platform such as a transportation app can provide arriving visitors with an easy option to explore the public transportation system with confidence.

\section{Discussion}

Currently, there is the application "Google Maps" that allows tourists to have an idea of how to use buses, metro and train in cities such as Porto and Lisbon. "Google Maps" is often not reliable especially if there is a delay due to traffic accidents. There is no app available for tourists that have been spearheaded by the local governments. The proposed digital platform from this project should work with the local government to improve the information that is already available. Before choosing a mode of choice for transportation, travelers can also be informed about the costs, environmental impacts as well as other necessary information to help them make the right decision.

\section{Conclusions}

By combining digital media and transportation, local government can improve the travel experience for tourists as well as help mitigate environment effects by providing them with information regarding public transportation. Working with arriving airlines and local governments to promote the usage of the digital transportation app, can ensure that the app is personalized and tailored to fit that particular city as soon as passengers land. In addition, while not everyone will be using the app for the last stretch of their journey from the airport to their hotel or Airbnb, those who are interested are more willing to learn about the environment, as well as the city that they are visiting so they will be able to put more effort towards reducing their environmental footprint.

\section{References}

Best Destinations in Europe. 2017. "Top destinations in Europe - Best places to travel in 2017". https://www.europeanbestdestinations.com/best-of-europe/european-bestdestinations-2017/.

Brasseur, G. P., M. Gupta, B. E. Anderson, S. Balasubramanian, S. Barrett, D. Duda, G. Fleming, et al. 2016. "Impact of aviation on climate: FAA's Aviation Climate Change Research Initiative (ACCRI) phase II". Bulletin of the American Meteorological Society 97, no. 4 (april): 561-83. https://doi.org10.1175/BAMS-D-13-00089.1.

Bugge, A. 2018. "Portugal's flourishing tourism becomes economic mainstay". https://www.reuters.com/article/us-portugal-tourism-idUSKCN1GS1YF.

Instituto Nacional de Estatística. 2018. Estatísticas do Turismo 2017. Lisboa: INE. https://www.ine.pt/xportal/xmain?xpid=INE\&xpgid=ine_publicacoes\&PUBLICACOESpub_ boui=337818849\&PUBLICACOESmodo $=2$.

International Civil Aviation Organization. 2018. "Continued passenger traffic growth and robust air cargo demand in 2017". https://www.icao.int/Newsroom/Pages/Continuedpassenger-traffic-growth-and-robust-air-cargo-demand-in-2017.aspx.

National Academies of Sciences, Engineering, and Medicine. 2008. Ground access to major airports by public transportation. Washington, DC: The National Academies Press. https://doi.org/10.17226/13918.

Pasha, M. M., and M. Hickman. 2016. "Airport ground accessibility: Review and assessment". Paper presented at the ATRF 2016 - Australasian Transport Research Forum 2016, 
Melbourne, Australia, November 16-18, 2016.

https://www.australasiantransportresearchforum.org.au/papers/2016.

Teixeira, F. 2017. "Portugal wins 37 awards at the world travel awards". Wine \& Food Travel Blog, October 6, 2017. https://blog.winetourismportugal.com/portugal-world-travelawards-winner-2017.

Turismo de Portugal. 2019. "Tourism of Portugal distinguished with 5 Awards of the Media Marketing \& Advertising Awards".

https://www.turismodeportugal.pt/pt/Noticias/Paginas/turismo-portugal-distinguidocom-premios-marketing-meios-publicidade.aspx.

World Tourism Organization (UNWTO). 2018. "UNWTO Tourism highlights: 2018 edition". https://www.e-unwto.org/doi/pdf/10.18111/9789284419876.

World Travel \& Tourism Council. 2018. "Travel \& tourism: Economic impact 2018: World". https://www.wttc.org/-/media/files/reports/economic-impact-research/regions2018/world2018.pdf.

\section{Acknowledgments}

University of Porto, Faculty of Engineering, Department of Informatics Engineering. 